\title{
ИЗ НАБЛЮДЕНИЙ НАД ТЕКСТОМ УТРЕННЕГО ЧТЕНИЯ НА ЧЕТВЕРГ ВЕЛИКОЙ НЕДЕЛИ В АРХАНГЕЛЬСКОМ ЕВАНГЕЛИИ 1092 ГОДА
}

\author{
A STUDY OF THE MORNING READING FOR HOLY THURSDAY \\ IN THE 1092 ARCHANGELSK GOSPEL
}

\author{
ZOFIA SZWED
}

\begin{abstract}
The article is an attempt to analyze the text of the morning reading for Holy Thursday in the 1092 Archangelsk Gospel referenced to the oldest Slavonic traditions of the Holy Bible translations. So far, researchers have focused on the morning reading for Holy Wednesday, which played an important role in the study of the complete edition of Aprakos Gospel. Less attention has been paid to the reading for Holy Thursday, a text which although textologically close to the reading for Holy Wednesday, is very different in the lexical dimension.
\end{abstract}

Zofia Szwed, Uniwersytet im. Adama Mickiewicza w Poznaniu, Poznań - Polska, z-szwed@amu.edu.pl

\section{1. Вводные замечания}

В Архангельском Евангелии (Арх. $\left.{ }^{1}\right)$ сохранились два утренних чтения Великой недели: на среду и на четверг. До сих пор внимание исследователей обычно сосредоточивалось на утреннем чтении на среду. Оно сыграло свою роль в исследованиях истории формирования славянских евангельских текстов. Л.П. Жуковская, например, в языковом материале перикопы нашла подтверждение концепции о полноапракосном характере оригинала, который использовал второй писец Арх., передвигая тем самым границу бытования на Руси полного апракоса к 1092 году². А.А. Пичхадзе, в свою очередь, использовала утреннее

\footnotetext{
${ }^{1}$ В статье употребляются также сокращения Арх.1 и Арх.2, относящиеся к частям Арх., переписанным двумя основными писцами книги с оригиналов двух разных редакций апракоса. Арх.1 охватывает листы 1-76, а Арх.2 - листы 77-175.

2 Концепция Л.П. Жуковской первоначально опиралась на текстологические факты, согласно которым состав чтений, предусмотренный для 7-й нд. поста (Великой недели) совпадает не с составом чтений в кратких апракосах XI в., а с составом чтений в полных апракосах типа Мстисл. Затем это положение было проверено и подтверждено на основании языковых данных утреннего чтения на Великую среду. См.: Л.П. Ж у к о в с к а я, Новые данные об оригиналах русской рукописи 1092 г., [в:] Источниковедение и история русского языка, Москва 1964, с. 88, 93.
} 
чтение на Великую среду в качестве примера перикопы, отражающей наиболее характерные языковые особенности преславской редактуры $^{3}$. Какое значение в исследованиях происхождения славянских служебных евангелий имеет утреннее чтение на четверг? Ему уделялось менее внимания, подобно как утренним чтениям на Великий понедельник и Великий вторник, которые, хотя в Арх. не сохранились, выступают в других списках. Внимательные наблюдения над утренними чтениями Великой недели помогли бы пролить свет на условия формирования полного апракоса либо, по крайней мере, апракоса с дополнениями ${ }^{4}$.

\section{2. Предмет и цель наблюдений}

В настоящей статье наблюдениям поддается утреннее чтение на четверг Великой недели, как единственное, рядом с утренним чтением на среду, сохранившееся в Арх. Рассматривается словарный состав этого чтения и аналогичных фрагментов Евангелия из других апракосных перикоп, а также соотнесенность анализируемой лексики с древними школами перевода. Целью является освещение истории утреннего чтения на Великий четверг, а также соотнесение полученных результатов с данными чтения на Великую среду. Сопоставление двух утренних чтений может приблизить нас к пониманию пути формирования полного апракоса.

\section{3. Утреннее чтение на Великий четверг и другие перикопы с текстом из XXII главы Евангелия от Луки}

На утрене в четверг Великой недели читается в Арх. и в ряде других полных апракосов фрагмент Евангелия от Луки XXII. 1-39. Текст входит в состав не только утреннего чтения на четверг Великой недели, но также и в состав других полноапракосных перикоп. Его разные фрагменты повторяются в чтениях на 12 пятницу нового лета и на понедельник сыропустный 5 . В противовес фрагменту Евангелия от Иоанна XII.

${ }^{3}$ А.А. П и ч х а д з е, Преславский полный апракос как свидетель кирилло-мефодиевского перевода Евангелия, „Slavia” 2009, roč. 78, Seš. 3-4, с. 438-439.

4 Не отрицая полностью концепцию Жуковской о полноапракосном происхождении Арх.2, Н.Б. Тихомиров склоняется к тезису о существовании, до появления полного апракоса, краткого апракоса с дополнениями. Представителем этой промежуточной редакции апракоса Н.Б. Тихомиров считает, между прочим, Арх. См.: Н.Б. Т и х о м и р о в, Каталог русских и славянских пергаменных рукописей XI-XII веков, хранящихся в Отделе рукописей Государственной библиотеки СССР имени В.И. Ленина, ч. III, дополнительная, „Записки Отдела рукописей”, Москва 1968, вып. 30, с. 106

5 Чтения на 12 пятницу нового лета и на понедельник сыропустный в Арх. не содержатся. 
17-47, т. е. утреннему чтению на среду, текст Евангелия от Луки XXII. 1-39 не имеет соответствия в краткоапракосных перикопах. Нижеприведенная таблица иллюстрирует полноапракосные перикопы с соответствующими строками Евангелия от Луки XXII. из Арх., Мстисл., Добрил. и Евсев.

\begin{tabular}{|c|c|c|c|c|}
\hline $\begin{array}{l}\text { Ев. от } \\
\text { Луки }\end{array}$ & Апракос & $\begin{array}{c}\text { Четверг утро Великой недели } \\
(1-39)\end{array}$ & $\begin{array}{c}12 \text { пятница } \\
\text { нового лета } \\
(1-8) \\
\end{array}$ & $\begin{array}{c}\text { Понедельник } \\
\text { сыропустный } \\
(9-39) \\
\end{array}$ \\
\hline \multirow{4}{*}{$\begin{array}{l}\text { Л. } \\
\text { XXII. } \\
2\end{array}$} & Apx.2 & $\begin{array}{l}\text { И ИСКААХОУ А ХХИЕ९ЕИ } \\
\text { и КМИЖКМИЦИ }\end{array}$ & - & - \\
\hline & Мстисл. & 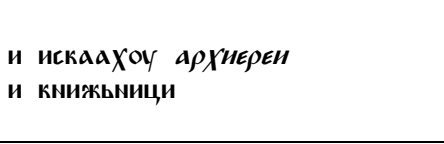 & 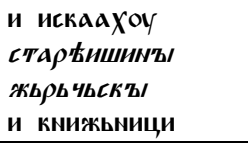 & - \\
\hline & Добрил. & 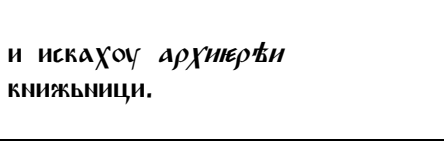 & 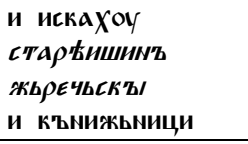 & - \\
\hline & Евсев. & 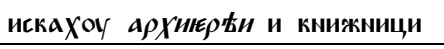 & - & - \\
\hline \multirow{4}{*}{$\begin{array}{l}\text { Л. } \\
\text { XXII. } \\
3\end{array}$} & Apx.2 & 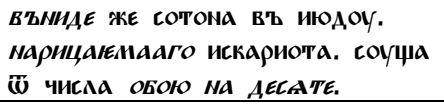 & - & - \\
\hline & Мстисл. & 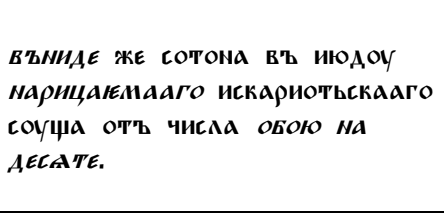 & 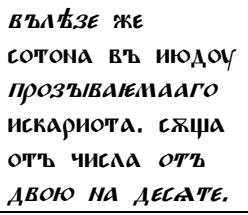 & - \\
\hline & Добрил. & 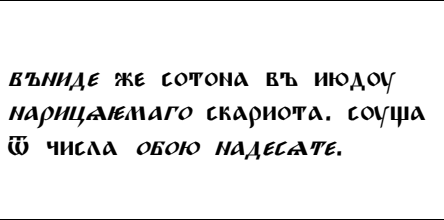 & 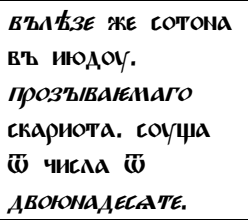 & - \\
\hline & Евсев. & 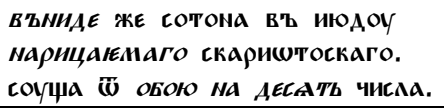 & - & - \\
\hline \multirow{4}{*}{$\begin{array}{l}\text { Л. } \\
\text { XXII. } \\
6\end{array}$} & Apx.2 & $\begin{array}{l}\text { И ИСПOВЪАА. И ИСКАШШЕ ПОАОБЬNА } \\
\text { ВРЕМЕNЕ. }\end{array}$ & - & - \\
\hline & Мстисл. & $\begin{array}{l}\text { и ИСПОВЪАА. И ИСКААШЕ } \\
\text { ПОАОБЬNА ВРЕМЕNЕ }\end{array}$ & $\begin{array}{l}\text { И OБКННАША. } \\
\text { И ИСКАШЕ ПОАОБЬNА } \\
\text { В९ЕМЕNE }\end{array}$ & - \\
\hline & Добрил. & И ИСКАШЕ ПОАОБNА В९ЕМЕNЕ & $\begin{array}{l}\text { И OБКНАША И } \\
\text { ИСКАШЕ ПОА(О)БЬNА } \\
\text { В९ЕМЕNE. }\end{array}$ & - \\
\hline & Евсев. & $\begin{array}{l}\text { ИСПОВЖАА И ИСКАШШ ПОАОБЬNА } \\
\text { ВРНМЕNЕ. }\end{array}$ & - & - \\
\hline
\end{tabular}

${ }^{6}$ Слово испов да или эвентуальный эквивалент отсутствует. 


\begin{tabular}{|c|c|c|c|c|}
\hline \multirow{4}{*}{$\begin{array}{c}\text { Л. } \\
\text { XXII. } \\
11\end{array}$} & Apx.2 & КАE IECTL OLÏTEAL. & - & - \\
\hline & Мстисл. & КАE IECTL OEHTRAL & - & $\begin{array}{l}\text { КАЕ IECT' } \\
\text { ВИТТААNИЦА }\end{array}$ \\
\hline & Добрил. & 7 & - & $\begin{array}{l}\text { КҚАЕ ІЕСТ' } \\
\text { ВИTААЬМИЦА. }\end{array}$ \\
\hline & Евсев. & KAE IECT' WE КT'ڤAL & - & - \\
\hline \multirow{4}{*}{$\begin{array}{c}\text { Л. } \\
\text { XXII. } \\
12\end{array}$} & Apx.2 & $\begin{array}{l}\text { И Т'Қ ВАМА ПОКАЖЕТЬ. } \\
\text { ГО९ЬМИЦЮ ВЕАИКОУ ПОСТЬААNОУ. }\end{array}$ & - & - \\
\hline & Мстисл. & $\begin{array}{l}\text { И Т'Ь ВАМА ПОКАЖЕТЬ ГО९ЬNИЦЮ } \\
\text { ВЕАИКХ ПОСТЬААNOY }\end{array}$ & - & $\begin{array}{l}\text { И Т'Қ ВАМА } \\
\text { ПОКАЖЕТЬ } \\
\text { ВҚСХОАЬМИЩЮ } \\
\text { ВЕАИКОУ } \\
\text { ПОСТЬААNOY. }\end{array}$ \\
\hline & Добрил. & $\begin{array}{l}\text { И Т'Қ ВАМА ПОКАЖЕТЬ } \\
\text { ГО९ЬМИЦОУ ВЕАИКОУ ПОСТЬМАNOY }\end{array}$ & - & $\begin{array}{l}\text { И Т'Қ ВАМА } \\
\text { ПОКАЖЕТЬ } \\
\text { ВЪСХОАNИЦЮ } \\
\text { ВЕАИКОУ } \\
\text { ПОСТЬААNOY. }\end{array}$ \\
\hline & Евсев. & $\begin{array}{l}\text { И Т'Қ ВАМА ПОКАЖЕТЬ. ГО९NИЩЮ } \\
\text { ВЕМИКОУ ПОСТААNOY. }\end{array}$ & - & - \\
\hline \multirow{4}{*}{$\begin{array}{c}\text { Л. } \\
\text { XXII. } \\
15\end{array}$} & Apx.2 & $\begin{array}{l}\text { ЖАДАМИЕМЬ ВЪЖ(А)ААХҚСА. СИю } \\
\text { ПаСХОУ ГАСТИ }\end{array}$ & - & - \\
\hline & Мстисл. & $\begin{array}{l}\text { Жадаминмь въЖААДаХҚ сию } \\
\text { пасХОУ ГАсти }\end{array}$ & - & 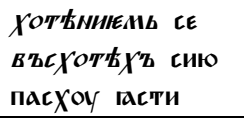 \\
\hline & Добрил. & $\begin{array}{l}\text { ЖАДАNЬЕМЬ ВЪЖАДАХZ СА СИЮ } \\
\text { ПАСХОУ ГАСТИ }\end{array}$ & - & 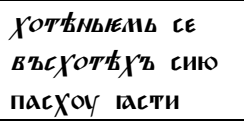 \\
\hline & Евсев. & $\begin{array}{l}\text { ЖАДАМЬЕМЬ ЖЕ ВZЖАДАХҚ СИЮ } \\
\text { ПАСКОУ ІАСТИ }\end{array}$ & - & - \\
\hline \multirow{4}{*}{$\begin{array}{l}\text { Л. } \\
\text { XXII. } \\
17\end{array}$} & Apx.2 & $\begin{array}{l}\text { И ПРИИМъ ЧАШЮ. ХВАКОУ } \\
\text { ВЪЗААВҚ РЕЧЕ. }\end{array}$ & - & - \\
\hline & Мстисл. & 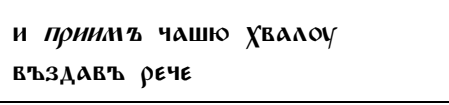 & - & 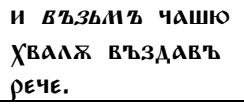 \\
\hline & Добрил. & 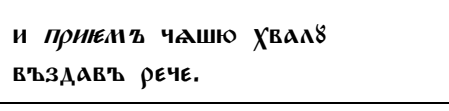 & - & $\begin{array}{l}\text { И ВҚЗЕМҚ ЧАШШОУ } \\
\text { ХВАNOY В'ҚЗААВ' } \\
\text { РЕЧЕ. }\end{array}$ \\
\hline & Евсев. & 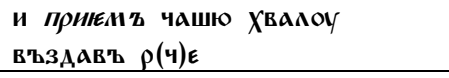 & - & - \\
\hline \multirow{4}{*}{$\begin{array}{c}\text { Л. } \\
\text { XXII. } \\
22\end{array}$} & Apx.2 & ОБАЧЕ ГО९Е ЧЙВКОУ ТОМОУ. & - & - \\
\hline & Мстисл. & ОБАЧЕ ГО९Е ЧМОВАКОУ ТОМВ & - & $\begin{array}{l}\text { ОБАЧЕ АЮТА } \\
\text { ЧК(О)ВКОУ ТОМУ }\end{array}$ \\
\hline & Добрил. & ОБАЧЕ ГО९Е ЧИ̃ВКОУ ТОМОУ & - & $\begin{array}{l}\text { OБАЧЕ АЮT' } \\
\text { Чล̃ВКОУ TOMOY }\end{array}$ \\
\hline & Евсев. & WЕАЧЕ ГО९Е ЧКЁКОУ ТОМОУ & - & - \\
\hline
\end{tabular}

7 Этот фрагмент чтения на утро Великого четверга в Добрил. отсутствует. 
Из наблюдений над текстом утреннего чтения на четверг Великой недели...

\begin{tabular}{|c|c|c|c|c|}
\hline \multirow{4}{*}{$\begin{array}{l}\text { Л. } \\
\text { XXII. } \\
25\end{array}$} & Apx.2 & 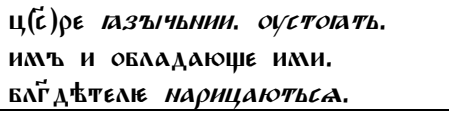 & - & - \\
\hline & Мстисл. & 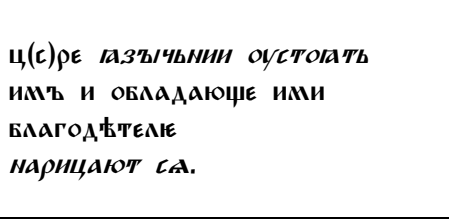 & - & 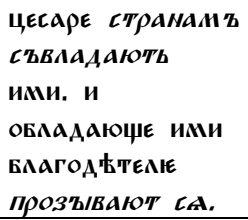 \\
\hline & Добрил. & 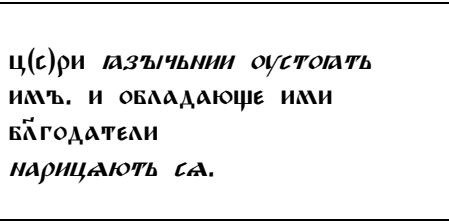 & - & 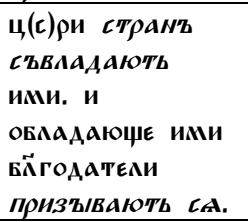 \\
\hline & Евсев. & 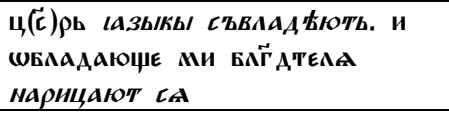 & - & - \\
\hline \multirow{4}{*}{$\begin{array}{l}\text { Л. } \\
\text { XXII. } \\
28\end{array}$} & Apx.2 & в' NaПастьX' моиХ'b. & - & - \\
\hline & Мстисл. & въ ManactьX' моиХ'ь. & - & $\begin{array}{l}\text { в' НСКОУШЕNИИХ'Ъ } \\
\text { МОИХ'Қ. }\end{array}$ \\
\hline & Добрил. & 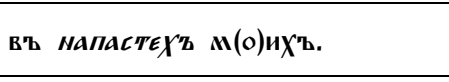 & - & 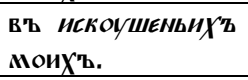 \\
\hline & Евсев. & в' NAПACTEX'Z МоиХ'Қ & - & - \\
\hline \multirow{4}{*}{$\begin{array}{c}\text { Л. } \\
\text { XXII. } \\
34\end{array}$} & Apx.2 & 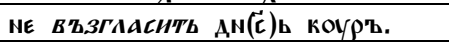 & - & - \\
\hline & Мстисл. & 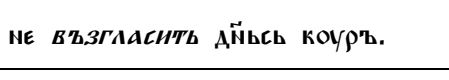 & - & 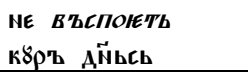 \\
\hline & Добрил. & NE ВZЗГААСИTЬ КOY९' АÑL. & - & 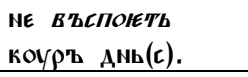 \\
\hline & Евсев. & 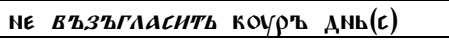 & - & - \\
\hline \multirow{4}{*}{$\begin{array}{c}\text { Л. } \\
\text { XXII. } \\
35\end{array}$} & Apx.2 & $\begin{array}{l}\text { БЕЗҚ ВЪААГААИНА. И БЕЗЪ } \\
\text { Пн९Ъ/. }\end{array}$ & - & - \\
\hline & Мстисл. & БЕЗҚ ВҚААГААИНА И БЕЗҚ Пи९Қ/ & - & $\begin{array}{l}\text { БЕЗһ СЪКОовИНа } \\
\text { И БЕЗ МћХа } \\
\end{array}$ \\
\hline & Добрил. & 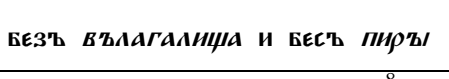 & - & 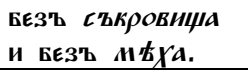 \\
\hline & Евсев. & БЕЗҚ ВААГААИНА И БЕ СПИ९Ь & - & - \\
\hline \multirow{2}{*}{$\begin{array}{l}\text { Л. } \\
\text { XXII. } \\
36\end{array}$} & Apx.2 & 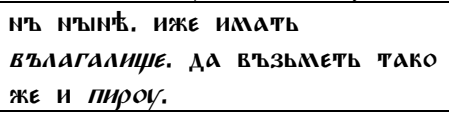 & - & - \\
\hline & Мстисл. & 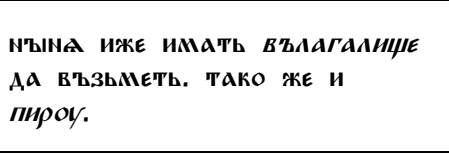 & - & 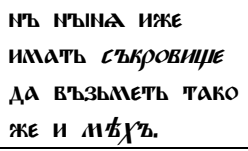 \\
\hline
\end{tabular}

8 的 спиры Вместо бес пиры - вероятно, ошибка издателя печатного текста. Возможно и другое объяснение: в памятнике вместо слова пира 'mošna, brašna; сумка' (SJS) ошибочно употреблено слово спира 'vojensky oddil, kohorta; отряд воинов, когорта'; оба слова имеют похожие греческие эквиваленты: пй а - опєіра; ср. также Л. XXII. 36 в Евсев. 


\begin{tabular}{|c|c|c|c|c|}
\hline & Добрил. & 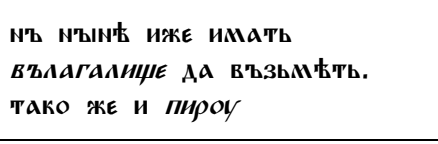 & - & 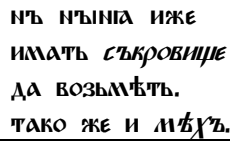 \\
\hline & Евсев. & $\begin{array}{l}\text { И NLIN' ЖЕ ВААГААИШЕ ИМАТЕ } \\
\text { АА ВОЗМЕТЕ. ТАКО ЖЕ И СПИ९ОУ. }\end{array}$ & - & - \\
\hline \multirow{4}{*}{$\begin{array}{c}\text { Л. } \\
\text { XXII. } \\
37\end{array}$} & Apx.2 & $\begin{array}{l}\text { IEЖE БO O MN'. KONЬ ЧИNOY } \\
\text { ИМАT'. }\end{array}$ & - & - \\
\hline & Мстисл. & $\begin{array}{l}\text { ИБО ІЕЖЕ О MN' КОNЬЧИNOY } \\
\text { ИМАT'. }\end{array}$ & 一 & $\begin{array}{l}\text { ИБО ІЕЖЕ О МNҢ } \\
\text { КОМЬЦЬ ИМАTЬ. }\end{array}$ \\
\hline & Добрил. & 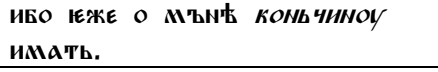 & - & $\begin{array}{l}\text { ИБО ІЕЖЕ О МN' } \\
\text { КОМЕЦЬ ИМАТЬ. }\end{array}$ \\
\hline & Евсев. & $\begin{array}{l}\text { ИБО ИЖЕ } W \text { MN' KONYИNOY } \\
\text { ИМАTЬ }\end{array}$ & 一 & - \\
\hline \multirow{4}{*}{$\begin{array}{c}\text { Л. } \\
\text { XXII. } \\
38\end{array}$} & Apx.2 & CE CAE NOжA AВA. & 一 & - \\
\hline & Мстисл. & CE CЬAE NOЖA АВA. & 一 & $\begin{array}{l}\text { LE MEYA CLAE } \\
\text { ABA. }\end{array}$ \\
\hline & Добрил. & LE СЬAE NOЖА АВА. & 一 & $\begin{array}{l}\text { CE NOFA CLAE } \\
\text { A'ҚBA }\end{array}$ \\
\hline & Евсев. & LE NOЖA АВA & 一 & - \\
\hline
\end{tabular}

Как видно из таблицы, текст Евангелия от Луки XXII. 1-39 в перикопе на четверг утро Великой недели в разных списках лексически однороден. Между отдельными перикопами имеются лексические различия, разночтения. В утреннем чтении на четверг, представленном в приведенных списках, отмечается другая лексика, чем в полноапракосных чтениях на 12 пятницу нового лета и на понедельник сыропустный. Если с точки зрения состава чтений можно поставить знак равенства между чтением на четверг и чтениями на 12 пятницу нового лета, а также на понедельник сыропустный, ибо они отмечаются только в полных апракосах, то относительно лексического состава знак равенства поставить нельзя. Утреннее чтение в четверг противостоит остальным полноапракосным чтениям 9 .

Лексическая синонимия в списках Евангелия связана с традицией перевода. Разночтения являются результатом замены первоначального, кирилло-мефодиевского перевода преславскими инновациями. Представителями старой переводческой традиции считаются тетраевангелия Зографское и Мариинское, а также древнейшие краткие апракосы: Ассеманиево Евангелие, Остромирово Евангелие 1056-1057 гг. и Саввина

\footnotetext{
9 Такое противопоставление характерно для церковнославянских полных апракосов русского извода. В сербских, позднейших списках, например в Вук. и Миросл., перикопы лексически унифицированы. Так, в Миросл. слова арХиєрєи, вьмиде, гормищю и т. д. отмечаются как в утреннем чтении в четверг, так и в чтениях на 12 пятницу нового лета и на понедельник сыропустный. В Вук. во всех перикопах наблюдаем слова: старћишимъ, вья Һзь, вьсходмицоу и т. д.
} 
книга. Преславские языковые черты нашли отражение прежде всего в церковнославянских полных апракосах русского извода. Они распределены в текстах апракосов неравномерно, в зависимости от специфики перикопы. Так, в краткоапракосном по происхождению цикле, от Пасхи до Пятидесятницы, преславские языковые черты представлены скудно по сравнению с полноапракосной перикопой на утро Великой среды, которая, как упоминалось в начале статьи, отражает наиболее характерные языковые особенности преславской редактуры ${ }^{10}$. В свете выводов А.А. Пичхадзе возникает вопрос об утреннем чтении на четверг. Какую переводческую традицию отражает эта перикопа?

\section{4. Соотнесенность лексики утреннего чтения на Великий четверг с древнейшей переводческой традицией}

В нижеприведенной таблице сопоставляются разночтения, отмеченные выше в Арх., Мстисл., Добрил. и Евсев., с соответствующими словами из тетраевангелий Зогр. и Мар., сохраняющих кирилло-мефодиевские варианты перевода.

\begin{tabular}{|c|c|c|c|c|c|}
\hline \multirow{2}{*}{$\begin{array}{c}\text { Ев. } \\
\text { от } \\
\text { Луки } \\
\text { XXII }\end{array}$} & $\begin{array}{c}\text { Утреннее } \\
\text { чтение на } \\
\text { четверг } \\
\text { Великой нд. }\end{array}$ & $\begin{array}{c}\text { Пятница } \\
12 \text { нового } \\
\text { лета }\end{array}$ & $\begin{array}{l}\text { Понедельник } \\
\text { сыропустный }\end{array}$ & \multirow[t]{2}{*}{ Зогр. } & \multirow[t]{2}{*}{ Map. } \\
\hline & $\begin{array}{r}\text { Арх.2, Мстисл., } \\
\text { Добрил., Евсев. }\end{array}$ & $\begin{array}{l}\text { Мстисл., } \\
\text { Добрил. }\end{array}$ & $\begin{array}{l}\text { Мстисл., } \\
\text { Добрил. }\end{array}$ & & \\
\hline 2 & 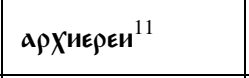 & $\begin{array}{l}\text { старђишина } \\
\text { жьрьчьскъ }\end{array}$ & & АРХИЕРЕи & А९ХИЕ९ЕИ \\
\hline 3 & въмити & въАЊсти & & В’Анити & в`мити \\
\hline 3 & марицати & ПрОЗ'ВВАТИ & & марицати & МАрицати \\
\hline 3 & овои & А'bвои & & овои & оБои \\
\hline 6 & ИСПОвЊААти & оБЊщати & & ИСПовЊААТи & ИсПовЊААТи \\
\hline 11 & овит中Аь & & вИТААЬАИЦА & окитЊАی & овит中Мь \\
\hline 12 & горьница & & въС ХОАьмица & горьница & горьница \\
\hline 15 & ЖАААNИІе & & Хот'ЊNйе & ЖЕतЊNИиЕ & 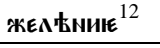 \\
\hline
\end{tabular}

10 А.А. П и ч х а д з е, указ. соч., с. $437,439$.

11 Написание слов унифицировано и сведено к исходной форме по SJS.

12 В пятнадцатой строке Евангелия от Луки XXII в разных списках отмечаются три лексических варианта: жАдамиє, Хот Ћмиє, жєл Һмиє. В старославянских памятниках письменности употребляются прежде всего два из них: жєл tмиє и хотьмиє 'желание' - оба употребляются на месте греческого єпьбиніа (СС). Слово жадамин 'желание', 'жажда' отмечено всего лишь дважды: в Синайском евхологии и Супрасльской

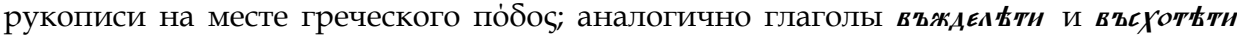

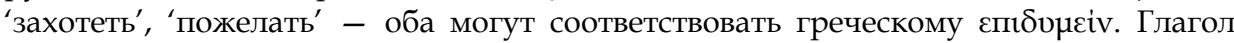

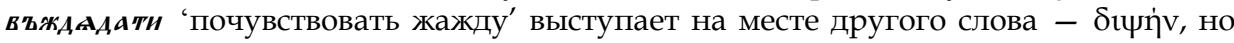




\begin{tabular}{|c|c|c|c|c|}
\hline 15 & вЪЖААААТИ & вЪСХотьти & в'ҚЖАЕ৯中тИ & 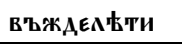 \\
\hline 17 & пригАти & въЗимати & пригАти & пригати \\
\hline 22 & rople & NЮT' & ГOpIE & rople \\
\hline 25 & |A.374/4h'h & стрANA & |А.3Қ|ЧЬN' & |A.374/4Nh \\
\hline 25 & $\begin{array}{l}\text { оустогтти, } \\
\text { съвмасти (Евсев.) }\end{array}$ & СЪВААСТИ & оустогтти & оустогтти \\
\hline 25 & МАрицАТИ СА & ПФОЗЪВАТИ СА & Марицати СА & марицати СА \\
\hline 28 & NAחACTh & ИСКОУШЕNИIE & Naחacth & NAחACTh \\
\hline 34 & вЪЗГААСИТИ & въсп巿ти & ВЪЗГААСИти & ВЪЗГКАСИТи \\
\hline 35,36 & ВЪМАГААИџІЕ & С'ҚКровице & ВЪААГАКИџЕ & ВЪМАГААИџЕ \\
\hline 35,36 & пира & Mt X'b & пира & пира \\
\hline 37 & коNьчина & коньць & коNьчима & КоNьчима \\
\hline 38 & Nожь & $\begin{array}{l}\text { МЕчь, } \\
\text { можь (ДобриЛ.) }\end{array}$ & ножь & Nожь \\
\hline
\end{tabular}

Из таблицы видно, что лексика утреннего чтения на четверг в полных апракосах совпадает с лексикой тетраевангелий - представителей кирилло-мефодиевского перевода. Старой переводческой традиции не соответствует лексика полноапракосных перикоп на 12 пятницу нового лета и на понедельник сыропустный.

Как упоминалось ранее, старую переводческую традицию отражают не только тетраевангелия Зогр. и Мар., но также древнейшие краткие апракосы: Ассем., Остр. и Савв. Ввиду того, что утреннее чтение на четверг Великой недели не имеет своего соответствия в кратких апракосах, прямое сравнение отдельных лексем невозможно. Тем не менее стоит проверить соотношение слов, образующих пары разночтений в текстах кратких апракосов в целом. В качестве сравнительного материала используется работа Т. Славовой, содержащая перечень 125 пар разночтений. Среди них находятся некоторые из отмеченных выше слов, выступающие в утреннем чтении на четверг Великой недели и в двух остальных полноапракосных перикопах с текстом Евангелия

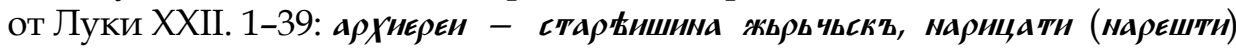

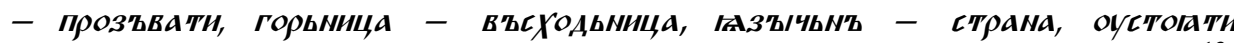

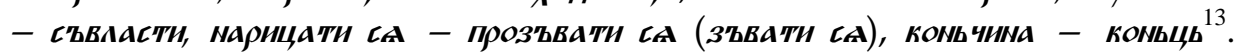
Т. Славова отмечает все случаи употребления приводимых ею слов в 35 евангельских текстах: апракосах и тетраевангелиях. Так, в кратких апракосах Ассем., Савв., Остр., Арх.1, подобно как в древнейших тетраевангелиях, она обнаруживает почти исключительно лексемы: архиєрєи (79×),

в противовес существительному жаданиє он часто выступает в старославянских списках, в том числе в Зогр. и Мар.

13 Т. С л а в о в а, Преславска редакция на Кирило-Методиевия старобългарски евангелски превод, „Кирило-Методиевски Студии”, София 1989, кн. 6. 


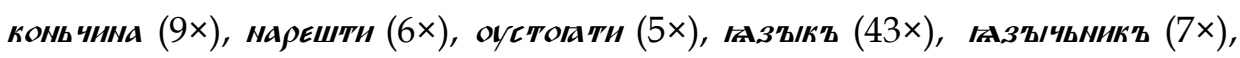
но: страма $(4 \times)$. В полных апракосах, Мстисл., Добрил., Юрьевском Евангелии, выступают прежде всего преславские инновации: старъишима жирьчьскъ (37×), прозтвати (4×), въсХодьмица (5×), страма (32×), съвАасти (4×), ПрозЪВати СА (ЗЪВати СА) (6×), Коньць $(4 \times)$, ОДНаКО ПОЯВЛЯюТСЯ И КИрилло-мефодиевские леКсемЫ: арХиєрєи (10×), марицати (марєшти) $(2 \times)$, горьмица (1×), ґАЗз/чьNъ (6×), конь чима $(4 \times)$. Таким образом, словарный состав проанализированных Т. Славовой древнейших тетраевангелий и кратких апракосов довольно однороден. Он представляет собой лексический слой, соответствующий кирилло-мефодиевской традиции перевода. Полные апракосы конца XI - начала XII веков очень сильно отражают влияние преславской школы, однако наряду с этим они сохраняют древнейшие лексические элементы.

\section{5. Текстологическая близость - разные традиции перевода}

Расположение синонимичных лексем в полных апракосах зависит от характера перикопы. В чтениях, совпадающих в кратких и полных апракосах, следует ожидать преобладания кирилло-мефодиевской лексики. В собственно полноапракосных перикопах сильнее проявляются преславизмы. Об этом свидетельствуют результаты анализа соотноше-

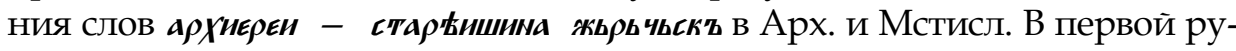
кописи отмечается почти исключительно лексема архиєрєи - 45× в перикопах краткоапракосных и $3 \times$ в утренних чтениях Великой недели. Словосочетание старъишима жьрь чьскұ, ввиду наличия немногих полноапракосных чтений в Арх., появляется только раз - в месяцеслове. В Мстисл. арХиєрєи отмечается 52× в краткоапракосных перикопах и 6× в полноапракосных, а старъишима жьрьчьскт - 3х в краткоапракосных перикопах и $34 \times$ в полноапракосных. Подобное соотношение имеется в парах разночтений: марицати - прозъвати, испов Аати - овћщати, овитћАь - витальмица, горьмица - въсХодьмица И, возможНО, также в других парах слов. Если наличие той или другой лексемы сильно зависит от характера перикопы, то как объяснить то, что столь близкие перикопы, как утренние чтения на среду и на четверг утро, которые отсутствовали в древнейших кратких апракосах и были прибавлены только в ходе редактирования полного апракоса или краткого с дополнениями, отражают разные традиции перевода? Возможно, что дополнительные чтения восходят к двум разным редакциям тетраевангелия либо они были прибавлены неодновременно, образуя очередные лексические слои. В связи с этим возникает вопрос о том, в какой последовательности прибавлялись к краткому апракосу утренние чтения Великой недели, а вслед за тем вопрос: может ли связь с более или менее древней переводческой традицией служить критерием хронологиза- 
ции процесса присоединения очередных чтений? Эти вопросы остаются открытыми. Ответ на них требует дальнейшего углубленного исследования всех утренних чтений в сопоставлении с другими перикопами ряда евангельских списков.

\section{6. Итоги}

Результаты наблюдений над лексикой утреннего чтения на четверг Великой недели позволяют утверждать, что текст Евангелия от Луки, имеющийся в Арх.2 и нескольких других апракосах, лексически не совпадает с соответствующими фрагментами того же Евангелия в полноапракосных перикопах на 12 пятницу нового лета и на понедельник сыропустный. Словарный состав чтения на четверг в проанализированных списках отражает кирилло-мефодиевскую традицию славянского перевода и отвечает лексике первых тетраевангелий Зогр. и Мар., а также древнейших кратких апракосов: Ассем., Остр. и Савв. Две полноапракосные перикопы с текстом XXII главы Евангелия от Луки, подобно как утреннее чтение на Великую среду, носят отпечаток преславской редактуры. Таким образом, столь текстологически близкие друг другу перикопы, как утренние чтения на среду и на четверг Страстной недели, обнаруживают различные пути создания.

\section{Список источников}

Арх. - Архангельское Евангелие 1092 года. Исследования, древнерусский текст, словоуказатели, изд. подг. Л.П. Жуковская и Т.Л. Миронова, Москва 1997.

Арx.1 - Арх., л. 1-76.

Aрx.2 - Aрх., л. 77-175.

Aссем. - Evangeliář Assemanův, J. Kurz, díl II, Praha 1955.

Вук. - - Вуканово Еванћље, Ј. Врана, Београд 1967.

Добрил. - Добрилове Евангеліе 1164 року, В.В. Німчук, Ю.В. Осінчук, Львів 2012.

Евсев. - - Евсевіеве Евангеліе 1283 року, В.В. Нимчук, Киів 2001.

Зогр. - Quattuor evangeliorum Codex glagoliticus olim Zographensis nunc Petropolitanus, V. Jagić, Berolini 1879, [в:] электронный ресурс: https://archive. org/stream/quattuorevangeli0 0jagiuoft\# page/n3/mode/2up

Мар. - Мариинское четвероевангелие. Памятник глаголической письменности, И.В. Ягич, Берлин 1883, [в:] электронный ресурс: https://docviewer. yandex.com/?url=ya-disk-public\%3A\%2F\%2FLacgVv2NduXXiDVNq0H urSpMD5TipZa6\%2 FdYgToE3XGM\%3D\&name=Yagich\%20I.V.\%20 Mariinskoe\%20chetveroevangelie. \% 20Pamyatnik\%20glagolic heskoj\%20pis'mennosti\%20(Berlin\%2C\%201883)(la)(K)(ToC)(300dpi)(637s). pdf\& page $=1 \& \mathrm{c}=53 \mathrm{e} 31 \mathrm{~d} 3 \mathrm{~d} 3438$ 
Миросл. - Мирослављево Јеванћеље, Н. Родић, Г. Јовановић, Београд 1986.

Мстисл. - Апракос Мстислава Великого, изд. подг. Л.П. Жуковская, Москва 1983.

Остр. - Остромирово ЕВангелие 1056-1057 г2. Факсимильное воспроизведение, Ленинград-Москва 1988.

Савв. $\quad$ - Саввина книга, изд. подг. В. Щепкин, Graz 1959.

\section{Библиография}

Ж у к о в с к а я Л.П., Новые данные об оригиналах русской рукописи 1092 г., [в:] Источниковедение и история русского языка, Москва 1964.

П и ч х а д з е А.А., Преславский полный апракос как свидетель кирилло-мефодиевского перевода Евангелия, „Slavia”, 2009, roč. 78, Seš. 3-4.

С л а в о в а Т., Преславска редакция на Кирило-Методиевия старобългарски евангелски превод, „Кирило-Методиевски Студии”, София 1989, кн. 6.

Т и х о м и р о в Н.Б., Каталог русских и славянских пергаменных рукописей XI-XII веков, хранящихся в Отделе рукописей Государственной библиотеки СССР имени В.И. Ленина, ч. III, дополнительная, „Записки Отдела рукописей”, Москва 1968, вып. 30.

СС - Старославянский словарь (по рукописям X-ХІ веков), под ред. Р.М. Цейтлин, Р. Вечерки и Э. Благовой, Москва 1994.

Grecko-polski Nowy Testament: wydanie interlinearne z kodami gramatycznymi, tłum. R. Popowski, M. Wojciechowski, Warszawa 1994.

Novum Testamentum Graece cum apparatu critic, curavit D. Eberhard Nestle. Novis curis elaboravit Erwin Nestle, Stuttgart 1930.

SJS - Slovník jazyka staroslověnského. Lexicon linguae palaeoslovenicae, t. I-IV (Seš. 1-52), Praha 1958-1997. 
